\title{
Generation IV Benchmarking of TRISO Fuel Performance Models under Accident Conditions - Modeling Input Data
}

Blaise P. Collin

September 2014
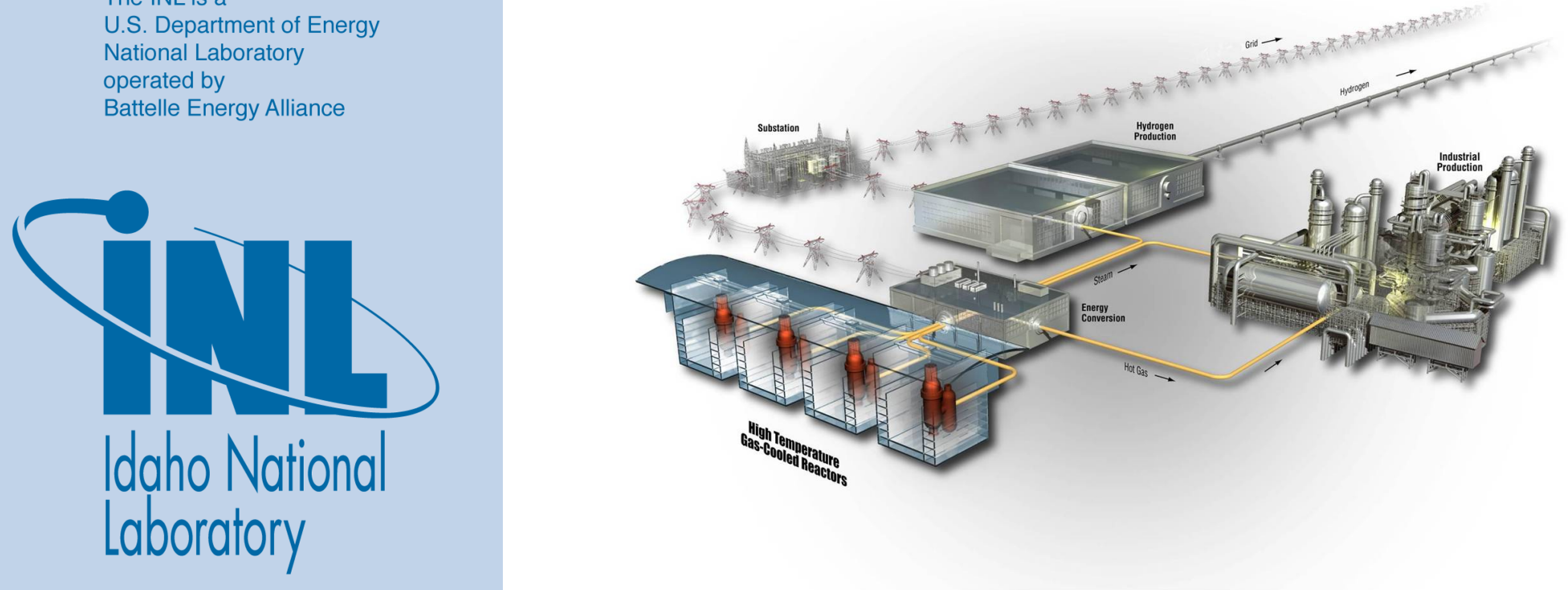


\section{DISCLAIMER}

This information was prepared as an account of work sponsored by an agency of the U.S. Government. Neither the U.S. Government nor any agency thereof, nor any of their employees, makes any warranty, expressed or implied, or assumes any legal liability or responsibility for the accuracy, completeness, or usefulness, of any information, apparatus, product, or process disclosed, or represents that its use would not infringe privately owned rights. References herein to any specific commercial product, process, or service by trade name, trade mark, manufacturer, or otherwise, does not necessarily constitute or imply its endorsement, recommendation, or favoring by the U.S. Government or any agency thereof. The views and opinions of authors expressed herein do not necessarily state or reflect those of the U.S. Government or any agency thereof. 


\title{
Generation IV Benchmarking of TRISO Fuel Performance Models under Accident Conditions Modeling Input Data
}

\author{
Blaise P. Collin
}

September 2014

\begin{abstract}
Idaho National Laboratory
VHTR Program

Idaho Falls, Idaho 83415
\end{abstract}

http://www.inl.gov

Prepared for the

U.S. Department of Energy

Office of Nuclear Energy

Under DOE Idaho Operations Office

Contract DE-AC07-05ID14517 

VHTR Program

Generation IV Benchmarking of TRISO Fuel Performance Models under Accident Conditions Modeling Input Data

INL/EXT-14-33117

September 2014

Prepared by:

Bhang Collin

Braise P. Collin

Approved by:

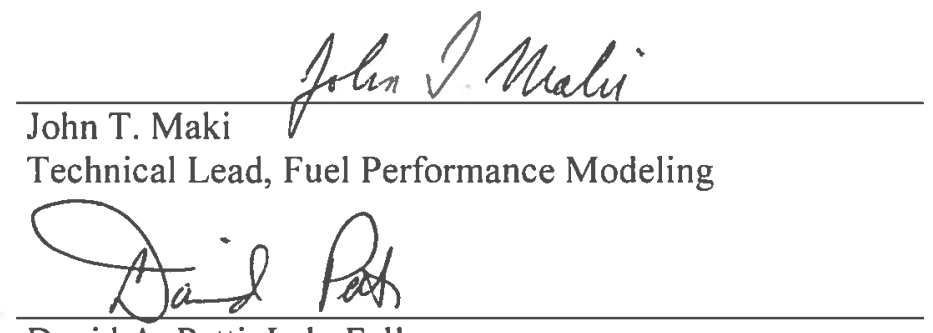

David A. Patti, Lab. Fellow

Director, Very High Temperature Reactor Program

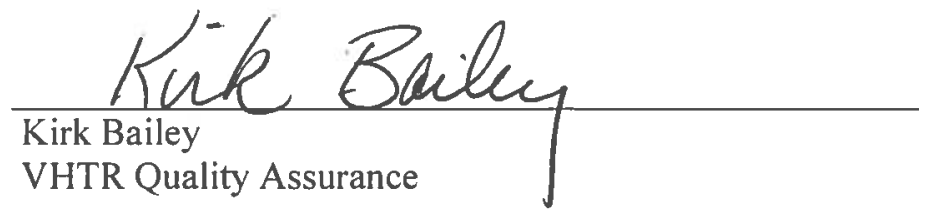

$9-24-14$

Date

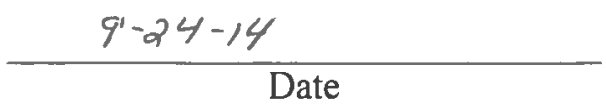

$9-24-14$

Date

$9 \cdot 24 \cdot 2014$ 



\begin{abstract}
This document presents the benchmark plan for particle fuel performance calculations of safety tests that are representative of accident transients.

The benchmark is developed in the frame of Generation IV, as a follow-on of a previous benchmark performed as part of the International Atomic Energy Agency (IAEA) Coordinated Research Program on coated particle fuel technology (CRP-6). The coordination effort for this benchmark is led by Idaho National Laboratory (INL).

The benchmark is dedicated to the modeling of fission product release under accident conditions by fuel performance codes from around the world, and the subsequent comparison to experimental data from the modeled safety tests. Safety tests chosen for modeling include the first experiment of the Advanced Gas Reactor program (AGR-1) and the High Flux Reactor (HFR) EU1bis experiment. Other experiments, such as AGR-2, may be added to the benchmark in the future.

Modeling of fission product release during these safety test experiments will be performed by the benchmark participants, and subsequent results will then be collected and compared to experimental data by INL.
\end{abstract}




\section{CONTENTS}

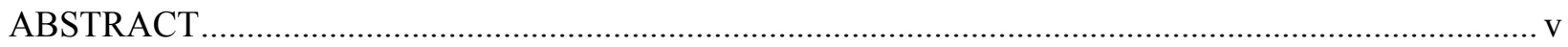

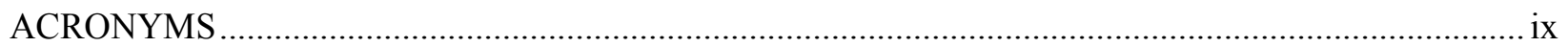

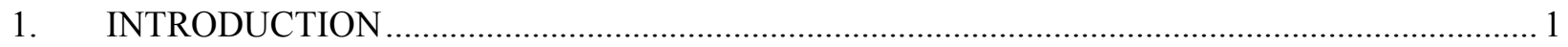

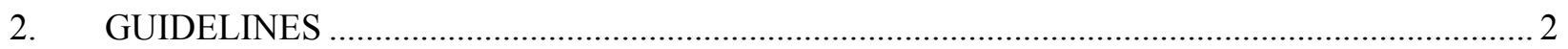

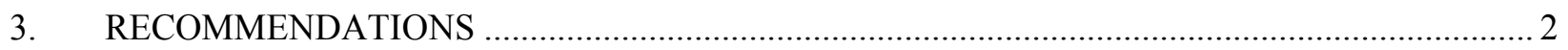

3.1 Numerical Calculation Case ....................................................................................... 3

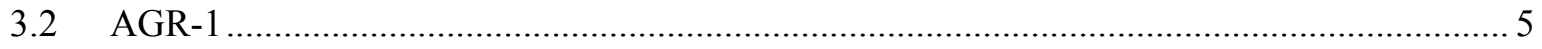

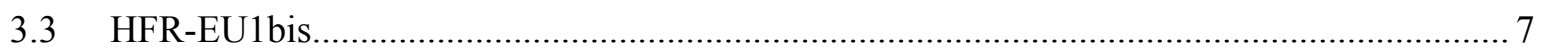

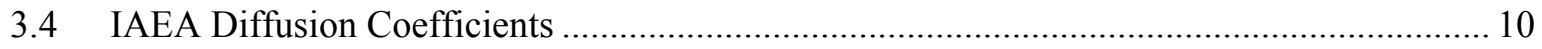

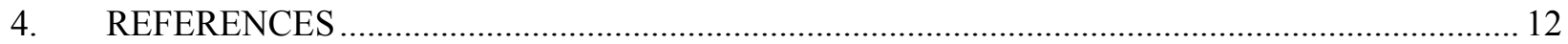

TABLES

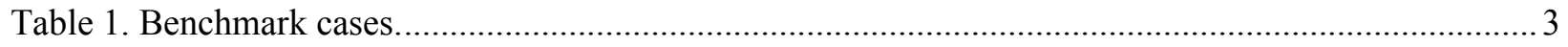

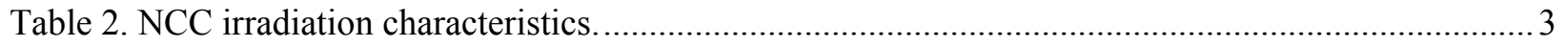

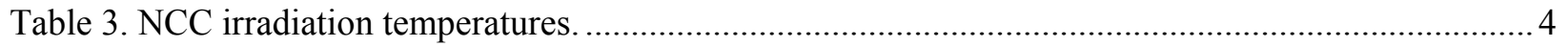

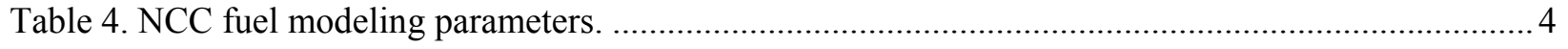

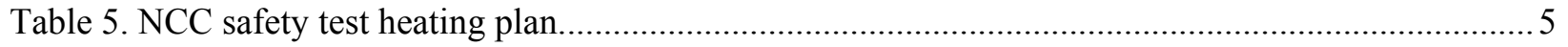

Table 6. AGR-1 compact selection and irradiation characteristics........................................................5

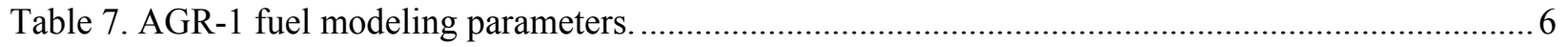

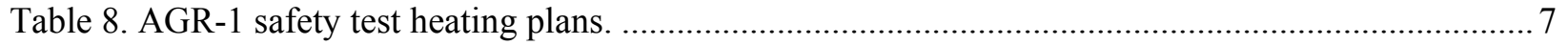

Table 9. HFR-EU1bis sphere selection and irradiation characteristics.................................................. 7

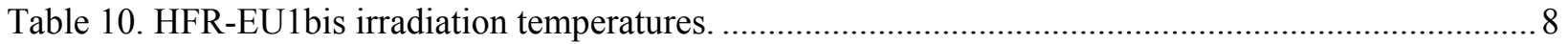

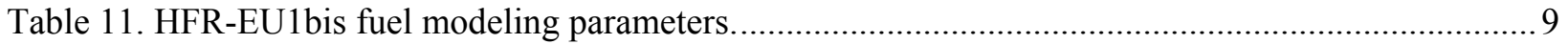

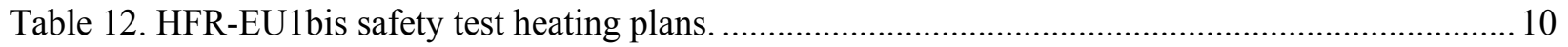

Table 13. Recommended IAEA diffusion coefficients.......................................................................... 11 


\section{ACRONYMS}

AGR Advanced Gas Reactor

CO Carbon monoxide

CRP Coordinated Research Program

EFPD Effective Full-Power Days

FIMA Fissions per Initial Metal Atom

FRG Federal Republic of Germany

HFR High Flux Reactor

IAEA International Atomic Energy Agency

INL Idaho National Laboratory

IPyC Inner Pyrocarbon

NCC Numerical Calculation Case

OPyC Outer Pyrocarbon

PARFUME PARticle FUel ModEl

SiC Silicon Sarbide

ST Safety Testing

TRISO TRistructural ISOtropic

UCO Uranium Oxycarbide

$\mathrm{UO}_{2} \quad$ Uranium Dioxide 


\section{Generation IV Benchmarking of TRISO Fuel Performance Models under Accident Conditions Modeling Input Data}

\section{INTRODUCTION}

This document presents the benchmark plan for particle fuel performance calculations of safety tests that are representative of accident transients.

The benchmark is developed in the frame of Generation IV, as a follow-on of a previous benchmark performed as part of the International Atomic Energy Agency (IAEA) Coordinated Research Program on coated particle fuel technology (CRP-6). The coordination effort for this benchmark is led by Idaho National Laboratory (INL).

The benchmark is dedicated to the modeling of fission product release under accident conditions by fuel performance codes from around the world, and the subsequent comparison to experimental data from the modeled safety tests. Safety tests chosen for modeling include the AGR-1 (Maki 2009) and HFREU1bis (Fütterer 2004) experiments. Other experiments, such as AGR-2, may be added to the benchmark in the future. At this point, the Safety Testing Plan for AGR-2 has not yet been finalized, so no guidelines or recommendations are provided for this experiment. The following guidelines and recommendations apply to the AGR-1 and HFR-EU1bis experiments only.

Modeling of fission product release during these safety test experiments will be performed by the benchmark participants, and subsequent results will then be collected and compared to available experimental data by INL. The accident benchmark is divided into three parts:

- The modeling of a simplified benchmark problem to assess potential numerical calculation issues at low levels of fission product release.

- $\quad$ The modeling of fission product release during the AGR-1 and HFR-EU1bis safety testing (ST) experiments.

- The comparison of all the AGR-1 and HFR-EU1bis modeling results with experimental data.

The simplified benchmark case, thereafter named NCC (Numerical Calculation Case), is derived from Case 5 of the IAEA CRP on coated particle fuel technology (IAEA 2012). It is included so participants can evaluate their codes at low levels of fission product release. Case 5 of the IAEA CRP-6 showed large code-to-code discrepancies in the release of fission products, which were attributed to the "effects of the numerical calculation method rather than the physical model" (IAEA 2012). The NCC is therefore intended to check if these numerical effects subsist.

The first two steps imply the involvement of the benchmark participants with a modeling effort following the guidelines and recommendations provided by this document. The third step involves the collection of the modeling results by INL and the comparison of these results with the available experimental data.

The objective of this document is to provide all necessary input data to model the benchmark cases, and to give some methodology guidelines and recommendations in order to make all results suitable for comparison with each other.

The participants should read this document thoroughly to make sure all the data needed for their calculations is provided in the document. Missing data will be added to a revision of the document if necessary. 


\section{GUIDELINES}

The modeling focuses on radiologically significant fission products. The key nuclides relevant to reactor safety and modeled in this benchmark are silver $(\mathrm{Ag})$, cesium $(\mathrm{Cs})$, strontium $(\mathrm{Sr})$, and krypton $(\mathrm{Kr})$. Other nuclides can have an impact on safety but they are encompassed with the above-mentioned fission products by lack of specific knowledge about their own diffusivities in TRISO particles. This is the case of europium whose diffusivity is assumed to be similar to that of strontium, or iodine and xenon which are assumed to be similar to krypton.

The AGR-1 and HFR-EU1bis experiments are to be modeled based on their respective specific experimental irradiation characteristics and fuel properties. On the other hand, NCC is a study case based on nominal fuel properties and irradiation characteristics suited to match the requirement of low levels of fission product release.

The following section presents the modeling data for the benchmark of NCC and the AGR-1 and HFR-EU1bis safety tests, and the recommended IAEA diffusion coefficients. AGR-1 irradiation temperatures are provided in the Excel document "Temperatures.xlsx". They correspond to predicted daily temperatures averaged over the volume of each compact (Hawkes 2012).

Material properties are not provided in this document, as each participant's code may use its own default correlations and values. In the event that a code does not have some of these material properties, they should be taken from "Case 5" of the IAEA TECDOC-1674 (Tables 9-6 and 9-8 of (IAEA 2012)).

For both the irradiation and the safety testing phases, results to be computed include:

- Failure probability vs. time (broken down by failure mechanism)

- Release fractions of $\mathrm{Ag}, \mathrm{Cs}, \mathrm{Sr}$, and $\mathrm{Kr}$ vs. time (release fractions are relative to total inventory produced during irradiation)

- Centerline temperature of the layers vs. time

- Pressure vs. time

- Fission gas and carbon monoxide (CO) inventories vs. time

\section{RECOMMENDATIONS}

The participants are asked to provide a short description of their modeling code for inclusion in the final report, similar to that provided to the IAEA TECDOC-1674 (IAEA 2012). In addition, they are encouraged to provide a list of the data they used from Tables 4, 7, and 11 (fuel modeling parameters). This will allow clarification of the input data needs for this benchmark and future benchmark projects. Finally, for the purpose of analysis of the results, participants are asked to provide a list of the material properties they used in their respective codes.

In some codes, fission product transport takes into account the effects of particle failures, which results in a fractional release that weighs the release from intact particles and from particles with failed $\mathrm{SiC}$ layers with the corresponding probability of failure of this $\mathrm{SiC}$ layer. In an attempt to better match experimental results from AGR-1 and HFR-EU1bis, it is desirable to decouple the effects of failure probability from fission product transport, which amounts to explicitly and separately model the fission product release from intact particles and from particles with both failed inner pyrocarbon (IPyC) and $\mathrm{SiC}$ layers. Results will then be combined to be compared to the measured releases. The diffusion of fission products through a failed layer can be simply modeled by setting a high diffusivity (typically $10^{-6} \mathrm{~m}^{2} / \mathrm{s}$ ) in that layer. 
In the case of AGR-1, some compacts are known to contain particles that have experienced failure of both their IPyC and SiC layers during safety testing. The selected compacts are listed in Table 6. Postirradiation examination analysis showed that the AGR-1 compacts selected for safety testing did not contain any particles with failed $\mathrm{SiC}$. Therefore, the modeling of failed coating layers should only be done for the safety testing phase, and failure should be assumed at time zero of the safety tests for these selected compacts.

In the case of HFR-EU1bis, no particle failure was reported during safety testing but the high level of measured cesium release might point to particles with failed $\mathrm{SiC}$ during the safety tests. Therefore, both intact particles and particles with failed IPyC and $\mathrm{SiC}$ layers should be modeled during safety testing for all four spheres, assuming failure from time zero of the safety tests.

On the other hand, NCC is aimed at checking for potential numerical issues with the calculation of fission product release in a test case designed to have a low $\mathrm{SiC}$ failure probability, so the decoupled calculation of the release from intact particles or from particles with failed layers is not requested.

Table 1 summarizes the benchmark cases and the requested ways of modeling fission product release. Depending on their capabilities, codes should model fission product diffusion weighed by the probability of failure of the $\mathrm{SiC}$ layer (coupled calculation) on the one hand, and the diffusion from intact particles and from particles with failed $\mathrm{IPyC}$ and $\mathrm{SiC}$ decoupled from any failure probability on the other hand. Because safety testing calculations follow irradiation calculations, separately modeling intact particles and particles with failed $\mathrm{SiC}$ implies two combination cases. Indeed, intact particles during irradiation can either stay intact during safety testing or fail their IPyC and $\mathrm{SiC}$ layers. Consequently, there are two "Irradiation/ST" combinations for AGR-1 and HFR-EU1bis: "Intact/Intact" and "Intact/Failed".

Table 1. Benchmark cases.

\begin{tabular}{|l|c|c|c|c|c|}
\hline \multirow{2}{*}{ Case } & \multirow{2}{*}{$\begin{array}{c}\text { Coupled failure } \\
\text { and diffusion }\end{array}$} & \multicolumn{4}{|c|}{ Decoupled failure and diffusion } \\
\cline { 3 - 6 } & & Intact particles & \multicolumn{2}{c|}{$\begin{array}{c}\text { Particles with both } \\
\text { failed IPyC and SiC }\end{array}$} \\
\cline { 3 - 6 } & Yes & Irradiation & ST & Irradiation & ST \\
\hline NCC & Yes & Yes & - & - & - \\
\hline AGR-1 & Yes & Yes & Yes & No & Yes \\
\hline HFR-EU1bis & Yes & Yes \\
\hline
\end{tabular}

\subsection{Numerical Calculation Case}

Table 2 provides the irradiation characteristics of the Numerical Calculation Case intended to check for potential numerical effects (IAEA 2012).

Table 2. NCC irradiation characteristics.

\begin{tabular}{|c|c|c|c|}
\hline Case & Burnup (\%FIMA) & $\begin{array}{c}\text { Fast Fluence } \\
\left(\mathbf{1 0} \mathbf{n}^{\mathbf{2 5}} \mathbf{\mathbf { m } ^ { 2 }}\right. \\
\mathbf{E}>\mathbf{0 . 1 8} \mathbf{~ M e V )}\end{array}$ & $\begin{array}{c}\text { Irradiation } \\
\text { Length (EFPD) }\end{array}$ \\
\hline NCC & 10 & 2 & 1000 \\
\hline
\end{tabular}

NB: Burnup and fast fluence assumed to follow linear evolution throughout irradiation.

Fast Fluence $(\mathrm{E}>0.18 \mathrm{MeV})=0.91 \times$ Fast Fluence $(\mathrm{E}>0.1 \mathrm{MeV})$ 
Table 3 contains the irradiation temperatures for NCC (IAEA 2012). It consists of ten successive linear ramps from 600 to $1000^{\circ} \mathrm{C}$ during an irradiation length of $100 \mathrm{EFPD}$ each.

Table 3. NCC irradiation temperatures.

\begin{tabular}{|c|c|c|}
\hline Cycle Number & Cycle EFPD & $\begin{array}{c}\text { Surface } \\
\text { Temperature }\left({ }^{\circ} \mathbf{C}\right)\end{array}$ \\
\hline 1 & 100 & Ramp $600 \rightarrow 1000$ \\
\hline 2 & 100 & Ramp $600 \rightarrow 1000$ \\
\hline 3 & 100 & Ramp $600 \rightarrow 1000$ \\
\hline 4 & 100 & Ramp $600 \rightarrow 1000$ \\
\hline 5 & 100 & Ramp $600 \rightarrow 1000$ \\
\hline 6 & 100 & Ramp $600 \rightarrow 1000$ \\
\hline 7 & 100 & Ramp $600 \rightarrow 1000$ \\
\hline 8 & 100 & Ramp $600 \rightarrow 1000$ \\
\hline 9 & 100 & Ramp $600 \rightarrow 1000$ \\
\hline 10 & 100 & Ramp $600 \rightarrow 1000$ \\
\hline
\end{tabular}

Table 4 contains the fuel modeling parameters for NCC (IAEA 2012).

Table 4. NCC fuel modeling parameters.

\begin{tabular}{|l|l|c|}
\hline \multirow{5}{*}{ Fategory } & Parameter & Mean Value \pm Standard Deviation \\
\hline \multirow{5}{*}{ Purticle properties } & U-235 enrichment $(\mathrm{wt} \%)$ & 10 \\
& Oxygen/uranium (atomic ratio) & 2 \\
& Carbon/uranium (atomic ratio) & 0 \\
& Uranium contamination fraction & 0 \\
\hline & Kernel diameter $(\mu \mathrm{m})$ & 350 \\
& Buffer thickness $(\mu \mathrm{m})$ & 100 \\
& IPyC thickness $(\mu \mathrm{m})$ & 40 \\
& SiC thickness $(\mu \mathrm{m})$ & 35 \\
& OPyC thickness $(\mu \mathrm{m})$ & 40 \\
& Kernel density $\left(\mathrm{g} / \mathrm{cm}^{3}\right)$ & 10.8 \\
& Kernel theoretical density $\left(\mathrm{g} / \mathrm{cm}^{3}\right)$ & 10.96 \\
& Buffer density $\left(\mathrm{g} / \mathrm{cm}^{3}\right)$ & 0.95 \\
& Buffer theoretical density $\left(\mathrm{g} / \mathrm{cm}^{3}\right)$ & 2.25 \\
& IPyC density $\left(\mathrm{g} / \mathrm{cm}^{3}\right)$ & 1.9 \\
& SiC density $\left(\mathrm{g} / \mathrm{cm}^{3}\right)$ & 3.20 \\
& OPyC density $\left(\mathrm{g} / \mathrm{cm}^{3}\right)$ & 1.9 \\
& IPyC anisotropy $(\mathrm{BAF})$ & 1.03 \\
& OPyC anisotropy $(\mathrm{BAF})$ & 1.03 \\
& Particle asphericity $(\mathrm{SiC}$ level $)$ & 1.0 \\
\hline Boundary conditions & Ambient pressure $(\mathrm{MPa})$ & 0.1 \\
\hline
\end{tabular}


Table 5 shows the heating plan for NCC (IAEA 2012). It consists of a temperature step from the final irradiation temperature of $1000^{\circ} \mathrm{C}$ to the safety test temperature of $1600^{\circ} \mathrm{C}$, where the temperature stays constant for 200 hours.

Table 5. NCC safety test heating plan.

\begin{tabular}{|c|c|}
\hline Time (hh:mn) & Temperature $\left({ }^{\circ} \mathbf{C}\right)$ \\
\hline $00: 00$ & 1000 \\
$00: 01$ & 1600 \\
$200: 01$ & 1600 \\
\hline
\end{tabular}

\subsection{AGR-1}

Table 6 provides the list of the AGR-1 compacts to be modeled during the irradiation and safety testing phases (Collin 2012). It includes the irradiation characteristics, the number of particles with failed $\mathrm{IPyC}$ and $\mathrm{SiC}$ layers to model during safety testing, and the type (variant) of the fuel in the selected compacts, which determines some of the fuel properties (see Table 7). The irradiation temperatures are provided in the Excel document "Temperatures .xlsx".

Table 6. AGR-1 compact selection and irradiation characteristics.

\begin{tabular}{|c|c|c|c|c|c|c|}
\hline $\begin{array}{l}\text { Safety Test } \\
\text { Temperature } \\
\left({ }^{\circ} \mathrm{C}\right)\end{array}$ & Compact & $\begin{array}{c}\text { Number of } \\
\text { particles with } \\
\text { failed SiC } \\
\text { during ST }\end{array}$ & $\begin{array}{c}\text { Burnup } \\
\text { (\%FIMA) }\end{array}$ & $\begin{array}{c}\text { Fast Fluence } \\
\left(10^{25} \mathrm{n} / \mathrm{m}^{2}\right. \\
\mathrm{E}>0.18 \mathrm{MeV})\end{array}$ & $\begin{array}{l}\text { Irradiation } \\
\text { Length } \\
\text { (EFPD) }\end{array}$ & Variant \\
\hline \multirow{2}{*}{1600} & $6-4-1$ & 1 & 13.22 & 2.43 & 620.2 & Baseline \\
\hline & $4-3-3$ & 0 & 18.52 & 4.16 & 620.2 & 3 \\
\hline \multirow{2}{*}{1700} & $4-4-3$ & 0 & 18.83 & 4.06 & 620.2 & 3 \\
\hline & $3-3-1$ & 4 & 19.00 & 4.23 & 620.2 & Baseline \\
\hline \multirow{4}{*}{1800} & $5-1-3$ & 7 & 18.17 & 3.82 & 620.2 & 1 \\
\hline & $4-4-1$ & 2 & 18.84 & 3.99 & 620.2 & 3 \\
\hline & $4-3-2$ & 5 & 16.24 & 3.68 & 620.2 & 3 \\
\hline & $3-2-3$ & 11 & 19.03 & 4.28 & 620.2 & Baseline \\
\hline \multirow{3}{*}{ Transient } & $1-4-2$ & 0 & 14.83 & 3.01 & 620.2 & 3 \\
\hline & $1-1-3$ & 0 & 15.21 & 2.86 & 620.2 & 3 \\
\hline & $1-1-1$ & 0 & 15.05 & 2.81 & 620.2 & 3 \\
\hline
\end{tabular}

NB: Burnup and fast fluence are assumed to follow linear evolution throughout irradiation.

Fast Fluence $(\mathrm{E}>0.18 \mathrm{MeV})=0.91 \times$ Fast Fluence $(\mathrm{E}>0.1 \mathrm{MeV})$ 
Table 7 provides the fuel modeling parameters for AGR-1 (Maki 2009 / CEGA 1993).

Table 7. AGR-1 fuel modeling parameters.

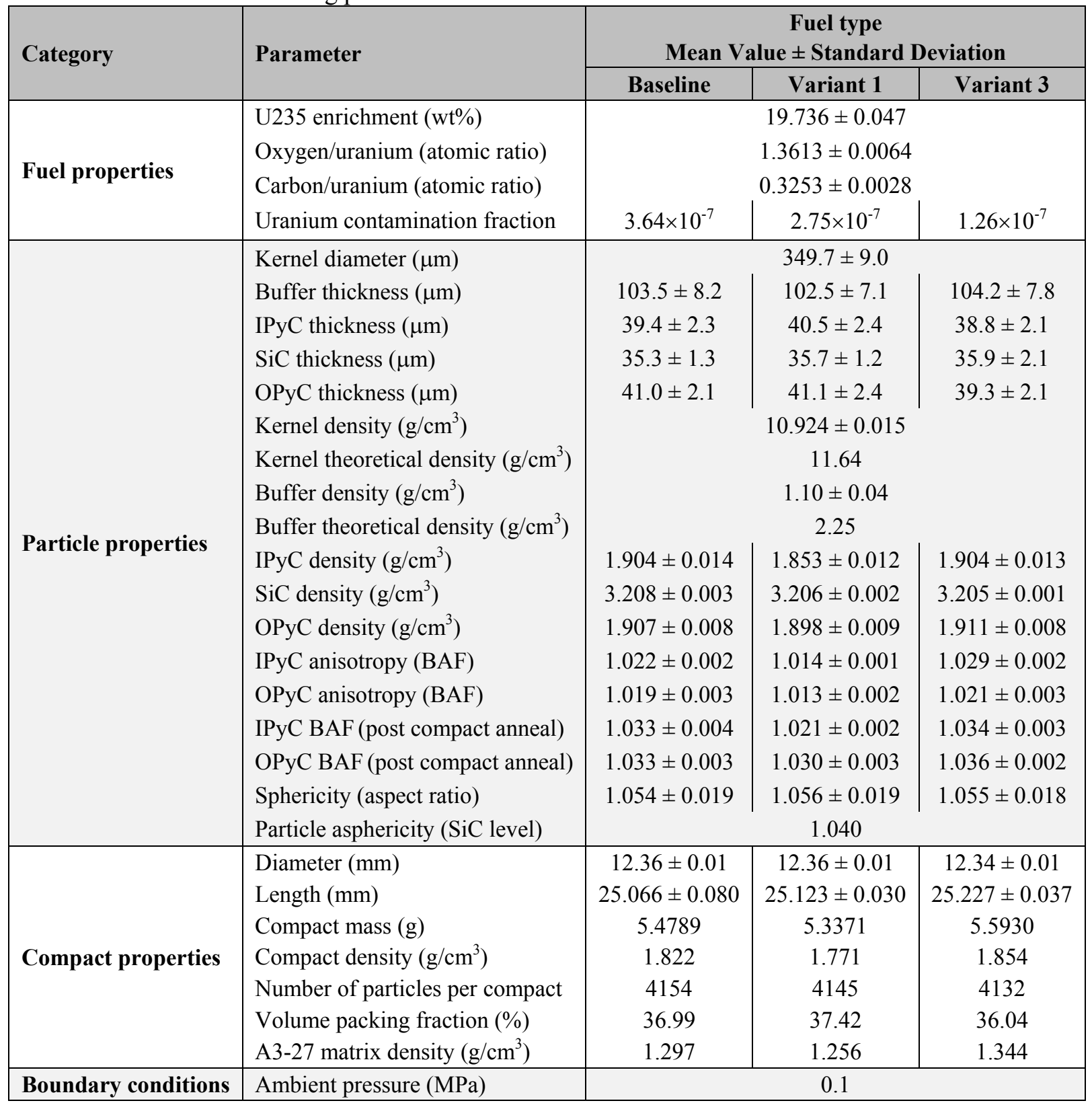

Note that AGR-1 fuel is UCO. Due to the lack of published UCO material properties and respective correlations, functional relationships for $\mathrm{UCO}$ are assumed to be the same as $\mathrm{UO}_{2}$. However, there should be no CO production associated with UCO fuel. 
Table 8 shows the heating plans for AGR-1 (Baldwin 2014). The evolution of the temperature between each time step is linear.

Table 8 . AGR-1 safety test heating plans.

\begin{tabular}{|c|c|c|c|c|c|c|c|}
\hline \multicolumn{2}{|c|}{ Transient } & \multicolumn{2}{|c|}{$1600^{\circ} \mathrm{C}$} & \multicolumn{2}{|c|}{$1700^{\circ} \mathrm{C}$} & \multicolumn{2}{|c|}{$1800^{\circ} \mathrm{C}$} \\
\hline Time (hh:mn) & $\mathbf{T}\left({ }^{\circ} \mathbf{C}\right)$ & Time (hh:mn) & $\mathbf{T}\left({ }^{\circ} \mathbf{C}\right)$ & Time (hh:mn) & $\mathbf{T}\left({ }^{\circ} \mathbf{C}\right)$ & Time (hh:mn) & $\mathbf{T}\left({ }^{\circ} \mathbf{C}\right)$ \\
\hline 00:00 & 20 & 00:00 & 30 & 0:00 & 30 & $0: 00$ & 30 \\
\hline $00: 30$ & 300 & 03:05 & 400 & 3:05 & 400 & $3: 05$ & 400 \\
\hline $22: 30$ & 300 & 05:05 & 400 & 5:05 & 400 & $5: 05$ & 400 \\
\hline $24: 00$ & 857 & $12: 10$ & 1250 & $12: 10$ & 1250 & $12: 10$ & 1250 \\
\hline 94:00 & 857 & $24: 10$ & 1250 & $24: 10$ & 1250 & $24: 10$ & 1250 \\
\hline $97: 48$ & 1300 & $31: 10$ & 1600 & $31: 10$ & 1700 & $31: 10$ & 1800 \\
\hline 105:06 & 1585 & $331: 10$ & 1600 & $333: 10$ & 1700 & $335: 10$ & 1800 \\
\hline 109:30 & 1652 & $333: 47$ & 30 & $335: 57$ & 30 & $338: 07$ & 30 \\
\hline $124: 00$ & 1695 & & & & & & \\
\hline $136: 00$ & 1680 & & & & & & \\
\hline $164: 00$ & 1620 & & & & & & \\
\hline 214:00 & 1508 & & & & & & \\
\hline 294:00 & 1342 & & & & & & \\
\hline 394:00 & 1200 & & & & & & \\
\hline 396:00 & 20 & & & & & & \\
\hline
\end{tabular}

\subsection{HFR-EU1bis}

Table 9 provides the irradiation characteristics of the HFR-EU1bis spheres to be modeled during the irradiation and safety testing phases (IAEA 2012).

Table 9. HFR-EU1bis sphere selection and irradiation characteristics.

\begin{tabular}{|c|c|c|c|}
\hline Sphere & Burnup (\%FIMA) & $\begin{array}{c}\text { Fast Fluence } \\
\left(\mathbf{1 0} \mathbf{2}^{\mathbf{2 5}} \mathbf{\mathbf { m } ^ { \mathbf { 2 } }}\right. \\
\mathbf{E}>\mathbf{0 . 1} \mathbf{~ M e V})\end{array}$ & Irradiation Length (EFPD) \\
\hline HFR-EU1bis/1 & 9.34 & 2.41 & 249.55 \\
\hline HFR-EU1bis/3 & 11.07 & 2.86 & 249.55 \\
\hline HFR-EU1bis/4 & 11.07 & 2.86 & 249.55 \\
\hline HFR-EU1bis/5 & 9.70 & 2.51 & 249.55 \\
\hline
\end{tabular}

NB: Burnup and fast fluence are assumed to follow linear evolution throughout irradiation.

Fast Fluence $(E>0.18 \mathrm{MeV})=0.91 \times$ Fast Fluence $(E>0.1 \mathrm{MeV})$ 
Table 10 provides the irradiation temperatures of the HFR-EU1bis spheres (Fütterer 2004). Temperatures are constant during each cycle.

Table 10. HFR-EU1bis irradiation temperatures.

\begin{tabular}{|c|c|c|c|c|c|c|c|c|c|c|}
\hline \multirow{2}{*}{ Cycle Number } & \multirow{2}{*}{ Cycle Name } & \multirow{2}{*}{ Cycle EFPD } & \multicolumn{6}{|c|}{ Surface Temperature $\left({ }^{\circ} \mathbf{C}\right)$} & \multicolumn{4}{|c|}{ Central Temperature $\left({ }^{\circ} \mathbf{C}\right)$} \\
\cline { 5 - 11 } & & & $\mathbf{1}$ & $\mathbf{3}$ & $\mathbf{4}$ & $\mathbf{1 5}$ & $\backslash \mathbf{1}$ & $\mathbf{3}$ & $\backslash \mathbf{4}$ & $\mathbf{5}$ \\
\hline 1 & $04-08$ & 24.97 & 1014 & 1009 & 1015 & 1006 & 1216 & 1250 & 1247 & 1227 \\
\hline 2 & $04-09$ & 24.72 & 1026 & 1024 & 1030 & 1020 & 1215 & 1251 & 1248 & 1227 \\
\hline 3 & $05-01$ & 25.99 & 1036 & 1038 & 1043 & 1032 & 1215 & 1252 & 1249 & 1228 \\
\hline 4 & $05-02$ & 25.67 & 1042 & 1047 & 1052 & 1040 & 1211 & 1249 & 1246 & 1224 \\
\hline 5 & $05-03$ & 25.29 & 1053 & 1062 & 1066 & 1052 & 1211 & 1252 & 1249 & 1226 \\
\hline 6 & $05-04$ & 25.67 & 1058 & 1072 & 1075 & 1060 & 1208 & 1251 & 1248 & 1224 \\
\hline 7 & $05-06$ & 24.26 & 1065 & 1082 & 1086 & 1069 & 1207 & 1252 & 1249 & 1224 \\
\hline 8 & $05-07$ & 25.19 & 1067 & 1088 & 1091 & 1073 & 1202 & 1248 & 1245 & 1220 \\
\hline 9 & $05-08$ & 22.19 & 1076 & 1101 & 1103 & 1083 & 1203 & 1253 & 1250 & 1223 \\
\hline 10 & $05-09$ & 25.60 & 1079 & 1108 & 1109 & 1088 & 1199 & 1252 & 1248 & 1220 \\
\hline
\end{tabular}


Table 11 provides the fuel modeling parameters for HFR-EU1bis (Nabielek 2005 / Pelletier 2003).

Table 11. HFR-EU1bis fuel modeling parameters.

\begin{tabular}{|c|c|c|}
\hline Category & Parameter & Mean Value \pm Standard Deviation \\
\hline Fuel properties & $\begin{array}{l}\text { U-235 enrichment (wt\%) } \\
\text { Oxygen/uranium (atomic ratio) } \\
\text { Carbon/uranium (atomic ratio) }^{(\text {a) }} \\
\text { Uranium contamination fraction }^{\text {(a) }}\end{array}$ & $\begin{array}{c}16.76 \\
2 \\
0 \\
7.8 \times 10^{-6}\end{array}$ \\
\hline Particle properties & $\begin{array}{l}\text { Kernel diameter }(\mu \mathrm{m}) \\
\text { Buffer thickness }(\mu \mathrm{m}) \\
\text { IPyC thickness }(\mu \mathrm{m}) \\
\text { SiC thickness }(\mu \mathrm{m}) \\
\text { OPyC thickness }(\mu \mathrm{m}) \\
\text { Kernel density }\left(\mathrm{g} / \mathrm{cm}^{3}\right) \\
\text { Kernel theoretical density }\left(\mathrm{g} / \mathrm{cm}^{3}\right) \\
\text { Buffer density }\left(\mathrm{g} / \mathrm{cm}^{3}\right) \\
\text { Buffer theoretical density }\left(\mathrm{g} / \mathrm{cm}^{3}\right) \\
\text { IPyC density }\left(\mathrm{g} / \mathrm{cm}^{3}\right) \\
\text { SiC density }\left(\mathrm{g} / \mathrm{cm}^{3}\right) \\
\text { OPyC density }\left(\mathrm{g} / \mathrm{cm}^{3}\right) \\
\text { IPyC anisotropy }(\mathrm{BAF}) \\
\text { OPyC anisotropy }(\mathrm{BAF}) \\
\text { Particle asphericity }(\mathrm{SiC} \text { level })\end{array}$ & $\begin{array}{c}502.2 \pm 10.6 \\
94.3 \pm 13.0 \\
40.6 \pm 3.7 \\
35.9 \pm 2.2 \\
39.8 \pm 3.3 \\
10.86 \\
10.96 \\
1.012 \\
2.2 \\
1.87 \\
3.20 \\
1.87 \\
1.02 \\
1.02 \\
1.04\end{array}$ \\
\hline Sphere properties & $\begin{array}{l}\text { Sphere diameter }(\mathrm{mm})^{(\mathrm{a})} \\
\text { Fuel zone diameter }(\mathrm{mm}) \\
\mathrm{U}-235 \text { content }(\mathrm{g} / \mathrm{pebble}) \\
\text { Heavy metal loading }(\mathrm{g} / \text { pebble) } \\
\text { Number of particles per sphere } \\
\text { Volume packing fraction }(\%) \\
\text { A3-3 matrix density }\left(\mathrm{g} / \mathrm{cm}^{3}\right)\end{array}$ & $\begin{array}{c}60 \\
50 \\
1.00 \pm 0.01 \\
6.0 \\
9560 \\
6.2 \\
1.75\end{array}$ \\
\hline Boundary conditions & Ambient pressure $(\mathrm{MPa})$ & 0.1 \\
\hline
\end{tabular}


Table 12 shows the heating plans for HFR-EU1bis (Freis 2009 / Verfondern 2013). The evolution of the temperature between each time step is linear.

Table 12. HFR-EU1bis safety test heating plans.

\begin{tabular}{|c|c|c|c|c|c|c|c|c|c|}
\hline \multicolumn{2}{|c|}{ HFR-EU1bis/1 } & \multicolumn{2}{|c|}{ HFR-EU1bis/3 } & \multicolumn{2}{|c|}{ HFR-EU1bis/4 } & \multicolumn{4}{|c|}{ HFR-EU1bis/5 } \\
\hline $\begin{array}{c}\text { Time } \\
\text { (hh:mn) }\end{array}$ & $\mathbf{T}\left({ }^{\circ} \mathbf{C}\right)$ & $\begin{array}{c}\text { Time } \\
\text { (hh:mn) }\end{array}$ & $\mathbf{T}\left({ }^{\circ} \mathbf{C}\right)$ & $\begin{array}{c}\text { Time } \\
\text { (hh:mn) }\end{array}$ & $\mathbf{T}\left({ }^{\circ} \mathbf{C}\right)$ & $\begin{array}{c}\text { Time } \\
\text { (hh:mn) }\end{array}$ & $\mathbf{T}\left({ }^{\circ} \mathbf{C}\right)$ & $\begin{array}{c}\text { Time } \\
\text { (hh:mn) }\end{array}$ & $\mathbf{T}\left({ }^{\circ} \mathbf{C}\right)$ \\
\hline 00:00 & 20 & 00:00 & 20 & $00: 00$ & 20 & $00: 00$ & 300 & $848: 00$ & 300 \\
\hline $00: 30$ & 300 & 01:00 & 20 & $00: 30$ & 300 & $16: 00$ & 300 & $850: 00$ & 1800 \\
\hline $06: 30$ & 300 & 01:30 & 300 & 03:30 & 300 & $23: 00$ & 950 & $852: 00$ & 300 \\
\hline 09:30 & 1250 & $04: 30$ & 300 & $05: 30$ & 800 & $126: 00$ & 950 & $854: 00$ & 1800 \\
\hline 209:30 & 1250 & 06:30 & 1250 & $53: 30$ & 800 & $136: 00$ & 300 & $856: 00$ & 300 \\
\hline $215: 30$ & 20 & $96: 00$ & 1250 & $56: 30$ & 1250 & $157: 00$ & 300 & $858: 00$ & 1800 \\
\hline $216: 30$ & 20 & 98:00 & 20 & $66: 30$ & 1250 & $161: 00$ & 950 & $860: 00$ & 300 \\
\hline 217:00 & 300 & 99:00 & 20 & $71: 30$ & 1320 & $185: 00$ & 950 & $862: 00$ & 1800 \\
\hline 220:00 & 300 & $99: 30$ & 300 & $76: 30$ & 1390 & $186: 00$ & 1050 & $864: 00$ & 300 \\
\hline 222:00 & 1250 & $102: 30$ & 300 & $86: 30$ & 1500 & 207:00 & 1050 & $866: 00$ & 1800 \\
\hline 232:00 & 1250 & 104:30 & 1250 & $91: 30$ & 1535 & 210:00 & 1250 & $868: 00$ & 300 \\
\hline $233: 30$ & 1320 & $114: 30$ & 1250 & $96: 30$ & 1570 & 280:00 & 1250 & $870: 00$ & 1800 \\
\hline $239: 30$ & 1600 & 118:00 & 1412 & $106: 30$ & 1630 & 284:00 & 1500 & 872:00 & 300 \\
\hline 439:30 & 1600 & $122: 00$ & 1600 & $115: 30$ & 1666 & $374: 00$ & 1500 & 874:00 & 1800 \\
\hline $455: 00$ & 20 & $322: 00$ & 1600 & $116: 30$ & 1670 & 378:00 & 1250 & $876: 00$ & 300 \\
\hline 456:00 & 20 & $324: 00$ & 20 & $126: 30$ & 1695 & 455:00 & 1250 & 878:00 & 1800 \\
\hline $456: 30$ & 300 & & & $136: 30$ & 1710 & 457:00 & 300 & 880:00 & 300 \\
\hline $459: 30$ & 300 & & & 140:00 & 1711.5 & 461:00 & 300 & 900:00 & 300 \\
\hline $461: 30$ & 1250 & & & $160: 30$ & 1720 & 481:00 & 1250 & 906:00 & 1800 \\
\hline $471: 30$ & 1250 & & & $280: 30$ & 1720 & 505:00 & 1250 & 980:00 & 1800 \\
\hline 473:00 & 1321 & & & 282:00 & 20 & 511:00 & 1600 & & \\
\hline 479:00 & 1605 & & & & & $624: 00$ & 1600 & & \\
\hline 481:00 & 1700 & & & & & 631:00 & 1800 & & \\
\hline 631:00 & 1700 & & & & & 821:00 & 1800 & & \\
\hline 646:00 & 20 & & & & & 844:00 & 300 & & \\
\hline
\end{tabular}

\subsection{IAEA Diffusion Coefficients}

The diffusive transport of fission products is calculated assuming that the fuel materials are homogeneous. Therefore, effective diffusion coefficients are used in code calculations. The set of data to be applied corresponds to the German ("FRG") diffusion coefficients, and Japanese diffusion coefficients for $\mathrm{Kr}$ in silicon carbide (SiC), from the IAEA TECDOC-978 (IAEA 1997). Table 13 provides these diffusion coefficients. 
Table 13. Recommended IAEA diffusion coefficients.

\begin{tabular}{|c|c|c|c|c|c|c|c|}
\hline & $\begin{array}{l}D_{0, \mathrm{i}}\left(\mathrm{m}^{2} / \mathrm{s}\right) \\
\mathrm{Q}_{0, \mathrm{i}}(\mathrm{kJ} / \mathrm{mol})\end{array}$ & Kernel & Buffer & PyC & $\mathrm{SiC}$ & $\begin{array}{c}\text { Matrix } \\
\text { graphite }\end{array}$ & $\begin{array}{c}\text { Structural } \\
\text { graphite }\end{array}$ \\
\hline \multirow{3}{*}{ Ag } & $D_{0,1}$ & $6.7 \times 10^{-9}$ & $10^{-8}$ & $5.3 \times 10^{-9}$ & $3.6 \times 10^{-9}$ & 1.6 & 1.6 \\
\hline & $\mathbf{Q}_{0,1}$ & 165 & 0 & 154 & 215 & 258 & 258 \\
\hline & $\begin{array}{l}\mathbf{D}_{0,2} \\
\mathbf{Q}_{0,2}\end{array}$ & - & - & - & - & - & - \\
\hline \multirow{3}{*}{ Cs } & $D_{0,1}$ & $5.6 \times 10^{-8}$ & $10^{-8}$ & $6.3 \times 10^{-8}$ & $5.5 \times 10^{-14} \times \mathrm{e}^{\Gamma / 4.5(b)}$ & $3.6 \times 10^{-4}$ & $1.7 \times 10^{-6}$ \\
\hline & $\mathbf{Q}_{0,1}$ & 209 & 0 & 222 & 125 & 189 & 149 \\
\hline & $\begin{array}{l}D_{0,2} \\
Q_{0,2}\end{array}$ & $\begin{array}{c}5.2 \times 10^{-4} \\
362\end{array}$ & - & - & $\begin{array}{c}1.6 \times 10^{-2} \\
514\end{array}$ & - & - \\
\hline \multirow{3}{*}{$\mathbf{K r}$} & $\mathbf{D}_{0,1}$ & $1.3 \times 10^{-12} / 8.8 \times 10^{-15(a)}$ & $10^{-8}$ & $2.9 \times 10^{-8}$ & $37 / 8.6 \times 10^{-10(c)}$ & $6.0 \times 10^{6}$ & $6.0 \times 10^{6}$ \\
\hline & $\mathbf{Q}_{0,1}$ & $126 / 54^{\text {(a) }}$ & 0 & 291 & $657 / 326^{(c)}$ & 0 & 0 \\
\hline & $\begin{array}{l}D_{0,2} \\
Q_{0,2}\end{array}$ & $\begin{array}{c}0 / 6.0 \times 10^{-1} \text { (a) } \\
0 / 480^{\text {(a) }}\end{array}$ & - & $\begin{array}{c}2.0 \times 10^{5} \\
923\end{array}$ & - & - & - \\
\hline \multirow{3}{*}{$\mathbf{S r}$} & $\mathbf{D}_{0,1}$ & $2.2 \times 10^{-3}$ & $10^{-8}$ & $2.3 \times 10^{-6}$ & $1.2 \times 10^{-9}$ & $10^{-2}$ & $1.7 \times 10^{-2}$ \\
\hline & $\mathbf{Q}_{0,1}$ & 488 & 0 & 197 & 205 & 303 & 268 \\
\hline & $\begin{array}{l}\mathbf{D}_{0,2} \\
\mathbf{Q}_{0,2}\end{array}$ & - & - & - & $\begin{array}{c}1.8 \times 10^{6} \\
791\end{array}$ & - & - \\
\hline
\end{tabular}

a. First values used in irradiation conditions / Second values used in accidental conditions.

b. $\Gamma$ : fast neutron fluence $\left(10^{25} \mathrm{n} / \mathrm{m}^{2}, \mathrm{E}>0.18 \mathrm{MeV}\right)$.

c. First values used above $1626 \mathrm{~K} /$ Second values used below $1626 \mathrm{~K}$.

$\begin{aligned} \mathrm{D} & =\mathrm{D}_{0,2} \mathrm{e}^{-\frac{\mathrm{Q}_{0,2}}{\mathrm{RT}}} \mathrm{D}_{0,1} \mathrm{e}^{-\frac{\mathrm{Q}_{0,1}}{\mathrm{RT}}}+\mathrm{D}_{0,2} \mathrm{e}^{-\frac{\mathrm{Q}_{0,2}}{\mathrm{RT}}} \\ \mathrm{D}_{0, \mathrm{i}} & =\text { pre-exponential factor }\left(\mathrm{m}^{2} / \mathrm{s}\right) \\ \mathrm{Q}_{0, \mathrm{i}} & =\text { activation energy }(\mathrm{kJ} / \mathrm{mol}) \\ \mathrm{R} & =\text { gas constant }\left(8.3142 \times 10^{-3} \mathrm{~kJ} / \mathrm{mol} / \mathrm{K}\right) \\ \mathrm{T} & =\text { temperature }(\mathrm{K})\end{aligned}$




\section{REFERENCES}

C. A. Baldwin, J. D. Hunn, R. N. Morris, F. C. Montgomery, C. M. Silva, P. A. Demkowicz, "First elevated-temperature performance testing of coated particle fuel compacts from the AGR-1 irradiation experiment", Nuclear Engineering and Design, 271 (2014) 131-141.

CEGA Corporation, "NP-MHTGR Material Models of Pyrocarbon and Pyrolytic Silicon Carbide", CEGA-002820, Rev. 1, July 1993.

B. P. Collin, “AGR-1 Irradiation Test Final As-Run Report”, INL/EXT-10-18097, Rev. 2, August 2014.

D. Freis, "Störfallsimulationen und Nachbestrahlungsuntersuchungen an kugelförmigen Brennelementen für Hochtemperaturreaktoren“, PhD Thesis, 2009.

M. A. Fütterer, H. Lohner, R. Conrad, K. Bakker, S. de Groot, and C. M. Sciolla, "HFR-Eu1bis Design and Safety Report", HTR-F-04/07-D-2.1.3, July 2004.

G. L. Hawkes, “AGR-1 Daily As-run Thermal Analyses,” ECAR-968, Rev. 3, May 2012.

IAEA, "Fuel performance and fission product behaviour in gas cooled reactors", TECDOC-978, November 1997.

IAEA, "Advances in High Temperature Gas Cooled Reactor Fuel Technology", TECDOC-1674, June 2012.

J. T. Maki, “AGR-1 Irradiation Experiment Test Plan”, INL/EXT-05-00593, Rev. 3, October 2009.

H. Nabielek, K. Verfondern, and H. Werner, "Selection of benchmark cases for mechanical failure prediction”, HTR-F1-04/08-D3.1.1, January 2005.

M. Pelletier, H. Nabielek, T. Abram, and D. Martin, "HTR-F Project: Selection of properties and models for the coated particle - Fuel kernel”, Technical Note CEA SESC/LSC 03-028, August 2003.

K. Verfondern, Private communication, November 2013. 